\title{
Locally Advanced Prostate Carcinoma
}

National Cancer Institute

\section{Source}

National Cancer Institute. Locally Advanced Prostate Carcinoma. NCI Thesaurus. Code C156285.

A prostatic carcinoma that has spread from its original site of growth to nearby tissues or lymph nodes. 